\title{
EXPLOITING SQ4R COOPERATIVE LEARNING METHOD TO ENHANCE EFL STUDENTS' READING COMPREHENSION
}

\author{
Ahmad Ridho Rojabi \\ IAIN Jember \\ ahmadridhorojabi@gmail.com
}

\begin{abstract}
This study was aimed at enhancing the ability of the thirty-six EFL students of the English Study Program at IAIN Jember in reading comprehension by exploiting the SQ4R method. To achieve the purpose, a collaborative classroom action research design was employed by following four stages: planning, implementing, observing, and reflecting. This study was implemented in two cycles, in which both the first cycle and the second cycle were carried out in two meetings. This method consists of five stages; survey, question, read, reflect, recite, and review. The steps of surveying and questioning were implemented in pre-reading, the steps of reading and reflecting were implemented in whilst-reading, while the steps of recite and review were implemented in post-reading. Overall, the study has revealed that the $S Q 4 R$ method enhanced students' reading comprehension as well as students' participation in the classroom.
\end{abstract}

Keywords: $S Q 4 R$, reading comprehension, classroom action research.

As a global language, learning English is important for people all over the world as English is the most commonly spoken language universally (Nishanthi, 2018; Sneddon, 2003). At university, all language skills need to be developed to improve students' abilities, the quality of teaching materials, as well as to overcome problems that arise in the teaching and learning process. In other words, they are expected to master four language skills namely: listening, speaking, reading, and writing.

According to Miller, cited by Shea \& Roberts (2016), reading is a journey both cognitive and emotional for the reader. In line with this idea, in reading, students are asked to convey the message of the author, construct meaning, identify main ideas and supporting ideas, and analyze vocabulary to find out contextual meaning. So, it can be concluded that reading is an important journey for the reader to achieve some information from various types of texts and for various purposes.

According to Urquhart and Weir in Zhang (2018), reading comprehension is defined as the process of receiving and integrating information from print media. In line with this idea, Santi (2015) explains that reading is a product of a process that operates during reading to create a representation of the situation described in the reading text.

Based on the above explanation, it can be concluded that reading comprehension is the process of interaction 
between written information and the reader by understanding written language related to the reader's language skills and the knowledge they have acquired. It means that the reader tries to comprehend the text by

$\ll \mid 2$ interpreting and understanding the text using their language skills as well as their background knowledge.

Furthermore, reading disabilities as one of the language skills becomes a problem faced by most EFL students that needs to be solved. To identify problems that occur in reading classes, the researcher conducted a preliminary study. Based on interviews in preliminary studies conducted with one of the English lecturers at IAIN Jember who teach Reading class, the lecturer often uses the lecture and question and answer method in teaching reading. Some students can understand the text well but some still have problems in reading text. The lecturer only uses textbooks in teaching reading. That is why some students may be bored in reading class activities and it affects their comprehending of the text given and their ability to solve reading questions. In brief, it was found that students faced some difficulties in reading comprehension due to a lack of strategies as well as interesting materials.

Based on the above reasons, the researcher tries to offer SQ4R as a teaching method in enhancing the EFL students' reading comprehension of the third semester at the English department who enrolled Interpretive Reading class. This also revealed that they had never exploited the SQ4R method in reading comprehension class activities since they were in Literal Reading and Inferential Reading courses. Therefore, it is interesting to know that the the SQ4R method can enhance the EFL students' reading comprehension at IAIN Jember in 2019/2020 academic year.
Some innovative learning methods can be implemented, and one of them is cooperative learning. Cooperative learning methods can be implemented in the classroom to train students' cooperative skills to share assignments, respect classmates, encourage asking questions, and encouraging friends to actively ask and answer questions. Therefore, cooperative learning methods are very effective as students can be actively involved and work together as a team to overcome the tasks. The cooperative learning method consists of several types of learning such as; Jigsaw, Think-Pair-Share, Numbered Head Together, Group Investigation, Two stay Two, SQ3R (Brown, 2007; Huda, 2014). The learning methods can be applied in teaching reading and one of them which is interesting for the researcher is SQ4R method, an updated version of SQ3R.

SQ4R is powerful to be applied in reading class. There are five steps that can be folowed where students use subtitles to develop questions that provide a framework for reading. The SQ4R method and all other reading methods share a basic organization. It covers a series of activities in pre-reading, whilst reading and post-reading. In brief, the stages describe specific activities that can be done by students before they read, when they read, and after they read.

The procedures in implementing the SQ4R method in teaching reading have several steps. First, in the step of surveying, students are asked to read quickly to find out the main ideas (Ratmaningsih, 2019). Surveying is an activity before reading a text by communicating through reading text, by reading the title and predicting information that will be read, reading the introduction and closing, and seeing any visual aids such as pictures, graphics, or illustrations. Based on the above ideas, it can be concluded that 
the survey is a pre-reading activity by looking at the title, introductory paragraph, concluding paragraph, as well as images to find out information in the reading text.

The second is the step of questioning. Students formulate questions to be answered as they read, by repeating the subtitles as questions (Ratmaningsih, 2019). Students develop questions that they expect to find the answer when they read the text. Students can write questions with what, why, who, when, where from the title, and the main ideas they got from the previous step. It can be concluded that the question stage is a student activity to formulate questions that can be answered when they read the reading text.

The third is the step of reading. Readers read to find out answers before reading the questions (Coon \& Mitterer, 2013). In this case, students are advised to read the material in each section to answer the questions they have formulated during the question stage. In line with this, it is suggested that in this step, students read the text by keeping questions in mind to look for answers to questions (Ratmaningsih, 2019). It can be concluded that reading is the activity of students reading the texts to find out answers to questions that have been formulated.

The fourth is the step of reflecting as a unity with the reading step. Carter cited by Basar \& Gurbuz (2017) argues that students think about and evaluate information obtained from reading and to find relationships with the reader's knowledge. They can make a correlation between their notes and their lives to help them easily remember the answers they made from the previous step. During reading, students not only simply memorize but they try to understand the information that is conveyed by; 1) linking information with things they already know, 2) Linking sub-topics in the text with the main concepts, 3) Trying to solve the contradictions from the information presented.

The fifth is the step of reciting. According to Carter cited by Basar \& Gurbuz (2017), reciting is a step to remember the main points of text without reading the text. When students complete a reading section, they must read the main points of that section. If they fail, then they must go back and re-read the passage. He further explained that reciting helps students transfer new material to their long-term memory. Furthermore, they can relearn quickly later. In short, reciting is a student's activity in transferring material to their longterm memory to remember the main points for answering questions that were formulated without rereading the material.

The sixth is the step of reviewing. Based on Carter cited by Basar \& Gurbuz (2017), in the final step, the reader does the repetition process for learning. Students look at their notes or even reread the text, but it is better for students should use their notes than texts to refresh their memories. It can be concluded that the aim of reviewing is to understand the main points of the reading text to answer the questions.

Some experts describe the advantages of SQ4R. The SQ4R method advises students to use what they already know to help them understand new material. This method asks readers to involve and use their background knowledge in reading activities and help them remember the content of materials better than just reading text material (Wood, 1996).

Brown (2007) explains that a set of effective procedures for approaching reading texts is SQ3R method, a process consisting of five steps; First, surveys help students to identify some important ideas from chapters and lessons. Second, questions help students 
to formulate questions and look for answers immediately. Third, reading helps students to concentrate on the text comprehensively. Fourth, reciting helps students to understand the text and repeat with their own words by

$\ll$ | 4 making concepts clearer than just memorizing the chapters of a book or the language used in a book. Finally, reviewing helps students to remember what they have learned through the series of learning procedures

Basar \& Gurbuz (2017) states that SQ4R aim is to develop students' cognition by reading text comprehensively, concentrate fully, and train the students' ability to improve their skills in guessing as well as critical thinking. This method can be used individually or even in a group for various subjects. In other words, this method can be applied not only in individual learning but also in the classroom with better instructions for each step.

Van den Broek cited by Santi (2015) explains that reading is a process that considers how the characteristics of the reader and the characteristics of text interact with each other. It means that there is an important interaction between language and mind when someone reads the text. The author encodes thought as language and the reader decodes language into thought. In short, students are expected to do more than just read the texts. They must recognize the printed material and convey its meaning. They can finally identify the message of the author which is expressed in the written text.

Peregoy \& Boyle (2017) defines reading as an interactive process whereby readers of both first and second languages use the knowledge of sounds, symbols, words, sentence structure to predict and obtain the meaning. Readers use their background knowledge about the topic of a text along with language knowledge and reading strategies to obtain the purpose of reading. For example, readers usually read a lot of reading texts but they lose their meaning. This means that they are not able to translate words and eventually, they lose connection with their meaning.

Furthermore, reading is an ability that should be possessed by students, especially in learning foreign languages. In line with this, Brown (2007) confirms that reading becomes one of the important skills to gain new knowledge. This can be accepted by some students who have disabilities, especially students who are blind. Although they cannot read, some of them can read by touching Braille to gain knowledge.

Comprehension includes the ability to understand what has been read or heard not only in individual sentences but also in longer discourses such as text sections or longer texts (Spear, 2015). While Snow (2002) argues that reading comprehension is the process of extracting and constructing meaning through interaction and involvement with written language. This is also the process of understanding the writer's writings. It starts with the eye being processed into the brain or the process of changing information from writer to reader. By doing so, one can understand the main source of the written language by reading.

Thus, reading comprehension is the process of interaction between written information and the reader by understanding written language that is related to the reader's language skills as well as the knowledge they have acquired.

In measuring the students' reading comprehension, the teacher must first define specific elements of reading comprehension that they want to score. Hennings (1997) suggests three levels of understanding, namely: understanding the meaning of words, understanding sentences, 
understanding paragraphs as well as understanding the whole text. Meanwhile, Barret cited by Brassell \& Timothy (2008) states that there are three levels of understanding; 1) literal comprehension, it is the ability to understand information which is explicitly stated in the text, 2) inferential comprehension, it is the ability to understand information which is not stated in the text, and 3) critical comprehension, it is the ability to evaluate text material.

In brief, the achievement of students-' reading comprehension in this study means the results achieved from students' reading comprehension tests which include the level of reading comprehension: identifying the meaning of words, identifying the sentences, identifying the main ideas of paragraphs, as well as identifying the whole text. Tests are given after they are taught with SQ4R in the classroom as part of the teaching method for reading.

\section{METHOD}

The design of this study was classroom action research conducted in the Interpretive Reading class of the thirdsemester students of the English department at IAIN Jember. It starts with identifying problems faced by students in reading skills, investigating class experiences, and taking actions on how to enhance students' reading comprehension through the SQ4R method. This is a reflective process that helps the researcher to explore and examine aspects of teaching and learning and take action to change and develop.

This research was conducted collaboratively with the lecturer of Interpretive Reading. Collaboration is defined as the cooperation of sharing ideas to take action as well as to solve problems. Furthermore, this action research is carried out in cycles where each cycle consists of four stages of activity: planning actions, implementing actions, observing classes, evaluating, and reflecting actions. In the planning stage, the researcher designs a lesson plan teaching method, teaching material, sets of the criteria of success and prepares a set of tests and observation guidelines. In the implementation stage, the SQ4R is implemented in the reading class during the class hours. In the observation stage, the students' participation is observed in the classroom by using observation checklist. And in the reflection stage, the researcher compares the result of conducted assessment and the criteria of success predetermined. If the results in a cycle had not achieved the criteria of success, the study was said unsuccessful and it would be necessary to design the following cycle by making an important revision.

The subjects of this study were 36 students of the third semester of the English department at IAIN Jember in 2019/2020 academic year who enrolled the Interpretive Reading course. The researcher is the lecturer of the Literal Reading and Inferential Reading course in the first semester and second semester, so to take the respondents, the researcher takes one class which has the lowest reading comprehension score to be a respondent or subject in this research. Therefore, the research result is only generalized to this class or research subject.

\section{RESULTS AND DISCUSSION Research Findings From Cycle 1}

In the first cycle, the researcher and the lecturer of Interpretive Reading discussed the SQ4R method to be applied in class, in this case, the researcher and the lecturer did it directly in class so that the researcher and the lecturer of Interpretive Reading get the 
same insight of how to teach reading comprehension by using the SQ4R method.

The reading materials taught in the first meeting and the second meeting were taken from the Longman Introductory

$<$ | 6 Course for the TOEFL Test. In the reading test, there were two texts which were taken from the book of Longman Complete Course for the TOEFL Test. The titles of the reading texts are "Solar Eclipse", and "Bald Eagle".

In cycle 1, the time allocation for the first meeting and the second meeting was 90 minutes including pre-reading, whilereading, and post-reading activities. In the pre-reading activity, the researcher introduced the survey and question stages. Formulating questions were given to introduce the topic and to activate the students' background knowledge about the topic of the text. Then, the researcher noted students' answers related to the topic on the whiteboard. The next step was to find out the main ideas of the topic.

Furthermore, in the whilst-reading activity, students were asked to read and reflect the three reading texts carefully and answered 20 question items. The last activity is the post-reading activity. Activities in this section were discussing additional information found from the reading texts and asking students to remember important points, and reviewing the reading texts. The next step was students had to answer reading questions based on the instructions given. After all, the researcher and students discussed the contents of the reading text.

Based on the classroom observation at the first meeting, it showed that 14 students or $38.89 \%$ of students were active in the teaching and learning process of reading by using the SQ4R method. While the classroom observation at the second meeting showed that 20 students or $55.56 \%$ of students were active in the teaching and learning process of reading by using the SQ4R method. It means that the observations in the first cycle have not been fulfilled because they have not met the standard requirements in this study. As a result, the action was continued into the second cycle.

A reading comprehension test was given at the end of the cycle to find out product evaluation. It was found that the percentage of students' reading test scores in the first cycle was $61.11 \%$ of the 22 students who achieved scored $\geq 60$. The action of this study was considered successful if $75 \%$ of the total number of students reached the targeted score $\geq 60$. In fact, there were 38.89 $\%$ (14 students) who achieved a reading score of $\geq 60$. This means that the target percentage of students who achieved scored $\geq 60$ had not yet been reached.

From the above results, it can be concluded that the action in the first cycle has not been successful. Therefore, it is necessary to proceed to the next cycle.

Reflection was based on the results of the reading comprehension test as well as observation. There were several factors that influence the results of the implementation of the actions in cycle I which cause unsuccessful; First, the SQ4R method is the first experience for students so they are still confused to apply the SQ4R method with the appropriate steps. Second, students still have difficulty in surveying the texts, formulating questions related to the topic, reading, reflecting, reciting and reflecting on reading texts comprehensively. Third, students cannot find the meaning of difficult words in reading text, besides they cannot get the main idea or supporting ideas from the reading text.

Due to the reading score results obtained by students who did not meet the standard requirements, the action in Cycle I was continued to Cycle 2 by revising some 
aspects needed from the first cycle. Dealing with students' difficulties in finding the meaning of certain words, the researcher and the lecturer of Interpretive Reading decided to allow students to bring their own dictionaries or borrow the dictionaries which is provided by the researcher and lecturer so that they could identify difficult words and find out their meaning easily and quickly.

In Cycle I, students were asked to find out the main ideas and supporting ideas of the reading texts in groups but they were not allowed to bring a dictionary. Then, in the second cycle, students were allowed to find out the main ideas and supporting ideas of the reading text in groups and bring a dictionary. This activity gave them the opportunity to find out the main ideas and supporting ideas easily, completely, and fast. By doing this kind of activity, students are expected to be able to share and discuss the contents of reading texts with their partners. Therefore, it is easier for them to understand the entire contents of the reading text, and they are able to answer the reading exercises correctly so that their achievement in reading comprehension can be increased as well. In the end, the results of the actions in the second cycle are expected to be better than the results of the actions in the previous cycle.

Moreover, the researcher needed to revise several aspects for further action. First, the researcher and the teacher needed to give more explanations, instructions, and examples of the SQ4R method in reading using English twice and the third explanation using Indonesian. Second, they provided more explanation on how to distinguish the main ideas and supporting ideas from the reading texts clearly and completely by distributing two authentic and enjoyable reading texts in each meeting. Third, they asked students to identify difficult words from the text and find out their meaning by looking at their own dictionaries. Fourth, students were asked to find out the main ideas and supporting ideas in cooperative learning. And finally, they provided more motivation as well as rewards for students who actively participated and were able to answer questions in the classroom.

\section{The Improvement of The Students' Reading Comprehension From Cycle 1 to Cycle 2}

The researcher made modifications in the second cycle because the results of students' scores in the first cycle did not meet the criteria of success. In fact, most students' scores are low; they were not able to understand words or phrases from the reading text, unable to find out the main ideas or supporting ideas. Thus, this method was modified in the second cycle by providing two reading texts in each meeting and students were allowed to open dictionaries, and they were allowed to discuss with their groups (cooperative learning) about the main ideas and supporting ideas of the reading text.

The implementation of the action was based on a revised lesson plan created by the researcher and the lecturer of Interpretive Reading collaboratively. The researcher hoped that after the action in the second Cycle, the student's reading test results were better than the first cycle and could enhance students' reading comprehension through the SQ4R method. The reading texts for the first meeting were taken from the Longman Introductory Course for the TOEFL Test while the reading texts for the second meeting were taken from the Longman Complete Course for the TOEFL Test.

Process evaluation used the observation list which was provided during the teaching and learning process of reading 
in each meeting of the second cycle. The indicators observed: surveying the reading text, formulating questions related to the topic, reading the text carefully, reflecting the reading text, reciting the main points, as

$<<\mid 8$ well as reviewing the reading text based on the instructions given.

At the end of the second cycle, a reading test was given to measure the students' reading comprehension. The titles of the text used in the reading comprehension test were "Desert Plants and American Jazz", both were taken from the Longman Complete Course for the TOEFL Test.

After taking action in Cycle 2 by revising some aspects needed, the percentage of students who achieved the minimum score requirement of reading test of at least 60 or more increased from $61.11 \%$ with 53.88 as the average score (Cycle 1) to $83.33 \%$ with an average score of 60.27 (Cycle 2).

In the first cycle in each meeting, there were $38.89 \%$ and $55.56 \%$ of students who actively participated in the teaching and learning process, but in the second cycle in each meeting there were $61.11 \%$ and $80.56 \%$ of students who were more actively participated in the teaching and learning process of reading. Furthermore, the enhancement of students' participation in the second cycle was followed by the percentage of students who achieved a reading score of $\geq 60$ in the reading comprehension test.

Table 1. The Improvement of the Percentage of Students' Reading Comprehension and Students' participation in Cycle 1 and Cycle 2

\begin{tabular}{|c|c|c|}
\hline Improvement & Cycle 1 & Cycle 2 \\
\hline $\begin{array}{l}\text { The percentage of } \\
\text { students } 61.11 \%\end{array}$ & $83.33 \%$ \\
\hline
\end{tabular}

\begin{tabular}{|l|l|l|}
\hline $\begin{array}{l}\text { achieved the } \\
\text { Reading score of } \geq \\
60\end{array}$ & & \\
\hline $\begin{array}{l}\text { The percentage of } \\
\text { the students' } \\
\text { participation in } \\
\text { reading class }\end{array}$ & $\begin{array}{l}38.89 \%, \\
\text { and }\end{array}$ & $\begin{array}{l}61,11 \%, \\
\text { and } \\
85,56 \%\end{array}$ \\
\hline
\end{tabular}

From the above table, it can be seen that in the first cycle, the percentage of students who obtained a reading comprehension test score of at least 60 or higher was $61.11 \%$, while in the second cycle is increased to $83.33 \%$. So, it can be concluded that the use of the SQ4R method can enhance the students' reading comprehension.

Based on the above findings, the results of this action research in two cycles proved the action hypothesis that "The use of the SQ4R method can improve the reading comprehension of EFL students" and "The use of the SQ4R method can improve the participation of EFL students in reading class".

\section{DISCUSSION}

The SQ4R method provides good implications for teachers and students. This really helps them to comprehend the reading text. The application of the SQ4R method which contains 6 steps helps the teacher to direct students in understanding the reading text.

The SQ4R method is very useful because the steps of surveying and questioning are able to activate their background knowledge. The steps of reading helps them to understand the main ideas and supporting ideas while the step of reciting, reflecting as well as reviewing help students remember important points from the reading text and monitor their own comprehension. This finding is in line with Huber (2004) who confirms that the 
SQ4R method is a very effective reading method which can be exploited by students in understanding reading texts by applying the six steps of activities, namely; survey, question, read, reflect, recite and review. Pre-reading surveys and questions help students focus their attention as well as concentration, generate reading interest, reduce their frustration level, increase their self-confidence, access their prior knowledge, predict what the writer will say, arrange writer's ideas, and understand the term and complicated vocabulary. The steps of reading and reflecting in whilst reading help students gain meaning, including a number of learning skills that help them concentrate, think, search, and understand ideas and concepts and how they relate the main ideas and supporting ideas as well. Finally, the steps of reciting and reviewing help students focus on their attention, to choose what is important to remember, and to rearrange the points in a form that makes sense to them.

Another previous study was carried out by Lestari (2011) with the title "Implementing SQ3R strategy to improve the students' reading comprehension at MTS Negeri Jambewangi Selopuro Blitar". The results showed that the SQ3R strategy improved the students' reading comprehension in descriptive texts. This improvement was revealed by the mean score of students who increased from 70.62 in the first cycle to 77.75 in the second cycle. Whereas Sada and Novita (2015) with the title "The use of the SQ4R method in improving the students' reading comprehension of recount text at SMPN Sungai Betung. They found out that the SQ4R method could help students improve their reading comprehension. This improvement was shown by the improvement of the students' mean score from 61.20 in cycle 1 to 86.40 in cycle 2 . Although the results of this study are in line with these two previous studies with an improvement on students' reading comprehension, this current study is different from these two previous studies where Lestari focuses on descriptive text, Sada and Novita focus on Recount text while this study focuses on Factual and Literary texts.

By modifying the class in the second cycle where students were allowed to discuss with their friends in a group which is called cooperative learning, this makes students interact and help each other in comprehending the text. This is in line with Renandya and Jacobs (2017) who confirm that cooperative learning not only puts students in a group to complete tasks, but they are also able to use language to interact meaningfully, have the same opportunity to convey ideas using the target language, and are able to repeat ideas when others do not understand their intention.

The reading text used in this study is Factual text which informs the reader about a subject by providing facts and information while the Literary text tells the reader a story or narrative and it contains fictional elements which require students to concentrate on the text and SQ4R method is very appropriate to be exploited. Basar \& Gurbuz (2017) explains that the aim of SQ4R is to develop students 'cognitive by comprehending, concentrating on the text, and practicing students' abilities to improve their skills in guessing and critical thinking.

The results of observations and reading comprehension tests in Cycle 1 and Cycle 2 showed that the SQ4R method could be applied as an effective method in teaching reading comprehension. In conclusion, the implementation of the SQ4R method could improve the reading comprehension of EFL students. 


\section{CONCLUSION}

The results of the discussion showed that the implementation of SQ4R method could enhance students' reading $<\mid \mathbf{1 0}$ comprehension as well as students' participation in the teaching and learning process of reading in the classroom. The procedures in applying the SQ4R method include survey, question, read, reflect, recite, and review need to be well implemented, sequentially conducted in groups so that students can cooperate and interact with each other in understanding reading texts. Furthermore, the need for patience and motivation from teachers is important to provide instructions in applying this method appropriately.

In conclusion, the SQ4R procedure as a teaching method facilitates students to enhance their reading comprehension by giving them many activities dealing with a variety of reading texts, such as surveying and formulating questions in pre-reading activities, reading and reflecting the texts in while reading activities, reciting important points, as well as reviewing text in postreading activities.

It is recommended to English teachers in exploiting the SQ4R method as an alternative method in teaching reading to enhance students' reading comprehension and students' participation. However, there are some students who still have difficulty in comprehending the text and some who are less active during the teaching and learning process in reading class. They are categorized as slow learners or they have low motivation in reading. These problems need to be further researched and solved. Thus, future researchers and English teachers who are more likely to experience the same problem are advised to conduct further classroom action research dealing with these problems to improve the quality of students' reading comprehension and students' participation.

\section{REFERENCES}

Basar, M., \& Gurbuz, M. (2017). Effect of the SQ4R Technique on the Reading Comprehension of Elementary School 4th Grade Elementary School Students. International Journal of Instruction, 2, 131-144.

Brassell, D., \& Timothy, R. (2008). Comprehension that Works Taking Students Beyond Ordinary Understanding to Deep Comprehension. Shell Education.

Brown, H. D. (2007). Teaching by Principles. An Interactive Approach to Language Pedagogy (Second Edi). Person Education, Inc.

Coon, D., \& Mitterer, J. O. (2013). Psychology: A Journey. Cengage Learning.

Hennings, D. C. (1997). Communication in Action: Teaching Literature-Based Language Arts (Sixth Edit). Houghton Mifflin Company.

Huber, J, A. (2004). A Closer Look at SQ3R. Journal Article, 41(4), 210-222.

Huda, M. (2014). Model-model Pengajaran dan Pembelajaran. Pustaka Pelajar.

Lestari, T. R. R. (2011). Implementing SQ3R Strategy to Improve the Students' Reading Comprehension. State University of Malang.

Nishanthi, R. (2018). The Importance of Learning English in Today World. International 
Journal of Trend in Scientific Research and Development, 3(1), 871-874.

Peregoy, S. F., \& Boyle, O. F. (2017). Reading, Writing, and Learning in ESL: A Resource Book for Teaching K-12 English Learners (Seventh Ed). Pearson Education, Inc.

Ratmaningsih, N. M. (2019). Metode dan Strategi Pembelajaran Bahasa Inggris. PT Rajagrafindo Persada.

Renandya, W., \& Jacobs, G. M. (2017). Cooperative Learning: Addressing Implemetation Issues. Indonesian JELT, 12(2), 101-113.

Sada, H. C., \& Novita, D. (2015). Improving Students' Reading Comprehension on Recount Text. Jurnal Pendidikan Pembelajaran, 4(6).

Santi, K. L. (2015). Improving Reading Comprehension of Middle and High School Students (D. K. Reed (ed.)). Springer International Publishing Switzerland.

Shea, M., \& Roberts, N. (2016). The Fives Strategy for Reading Comprehension. Learning Sciences International.

Sneddon, J. (2003). The Indonesian language, Its History and Role in Modern Society. NSW Press.

Spear, S. L. (2015). The Power of RTI and Reading Profiles. A Blueprint for Solving Reading Problems. Paul H. Brooks Publishing Co.,Inc.

Wood, N. V. (1996). College Reading and Study Skills: Learning, Thinking, Making Connection (Fifth Edit). Harcourt Brace College Publishers.

Zhang, L. (2018). Metacognitive and Cognitive Strategy Use in Reading Comprehension. Springer Nature Singapore Pte Ltd. 
$\longrightarrow$

$<\mid 12$ 